\title{
ANALISIS POLA TANAM DAN KALENDER TANAM PADI SAWAH MENGGUNAKAN DATA CITRA LANDSAT 8 OLI TIRS DI DAERAH IRIGASI BATANG ANAI KABUPATEN PADANG PARIAMAN
}

\author{
Deni Saputra $^{1}$, Eri Gas Ekaputra ${ }^{2}$, dan Santosa ${ }^{2}$ \\ ${ }^{1}$ Mahasiswa Program Magister Teknik Pertanian, Universitas Andalas \\ ${ }^{2}$ Dosen Fakultas Teknologi Pertanian, Universitas Andalas \\ Email: saputradenitep@gmail.com
}

\begin{abstract}
ABSTRAK
Pertumbuhan tanaman padi dipengaruhi oleh faktor pendukung alami yaitu iklim dan tanah, kendala yang sering dihadapi terjadinya perubahan iklim global yang berdampak terhadap pola curah hujan di berbagai wilayah. Dalam menentukan pilihan pola tanam yang efisien pada areal pertanian padi sawah, maka diperlukan upaya monitoring yang mampu mengamati, menganalisis, menyajikan dan memunculkan model keputusan, sehingga aktifitas pertanian padi sawah dapat dilakukan pada waktu yang tepat secara berkelanjutan. Penginderaan jauh (remote sensing) telah berkembang pesat dan penerapannya semakin luas untuk berbagai bidang, salah satunya pada sektor pertanian. Algoritma indeks vegetasi Normalized Difference Vegetation Indeks (NDVI) dan Enhanched Vegetation Indeks (EVI) untuk melakukan identifikasi fenologi tanaman padi. Melalui identifikasi umur tanam padi dapat diketahui pola tanam dan kalender tanam di daerah irigasi Batang Anai. Pola tanam interpretasi citra Landsat 8 selama 6 tahunan dengan menggunakan algoritma NDVI dan EVI adalah 2 kali setahun, musim tanam I pada bulan Januari dan musim tanam II pada bulan Juli. Pola tanam berdasarkan kondisi klimatologi adalah 2,5 kali setahun, musim tanam I pada bulan Januari, musim tanam II pada bulan Juni dan musim tanam III pada bulan November. Musim tanam IV pada bulan Maret dan musim tanam V pada bulan Agustus tahun berikutnya. Sebaran pola tanam dan kalender tanam berdasarkan interpretasi citra Landsat 8 dapat menjadi acuan, karena merupakan kebiasaan masyarakat setempat dan didukung oleh ketersediaan air dari curah hujan dan air irigasi. Kata kunci - EVI; kalender tanam; landsat 8; pola; remote sensing; NDVI
\end{abstract}

\section{PENDAHULUAN}

Pertumbuhan tanaman padi dipengaruhi oleh faktor pendukung alami yaitu iklim dan tanah, kendala yang sering dihadapi terjadinya perubahan iklim global yang berdampak terhadap pola curah hujan di berbagai wilayah. Curah hujan merupakan salah satu sumber ketersediaan air utama, kepastiannya akan beresiko pada tanaman padi terhadap kekurangan atau kelebihan air terutama saat fase generatif, akibatnya produksi tidak optimal, sehingga akan berpengaruh terhadap terjadinya kerawanan pangan, untuk mengatasinya perlu ditentukan kalender tanam dan pola tanam.

Dalam menentukan pilihan pola tanam yang efisien pada areal pertanian padi sawah, maka diperlukan upaya monitoring yang mampu mengamati, menganalisis, menyajikan dan memunculkan model keputusan, sehingga aktifitas pertanian padi sawah dapat dilakukan pada waktu yang tepat secara berkelanjutan. Pola tanam merupakan gambaran rencana tanam berbagai jenis tanaman yang akan dibudidayakan dalam suatu lahan beririgasi maupun tidak beririgasi dalam satu tahun (Rahma et al., 2018).

Teknologi penginderaan jauh (remote sensing) telah berkembang pesat dan penerapannya semakin luas untuk berbagai bidang, salah satunya pada sektor pertanian. Penginderaan jauh merupakan suatu ilmu dan seni untuk memperoleh informasi tentang suatu objek, daerah atau fenomena melalui analisis data yang diperoleh dengan suatu alat tanpa kontak langsung dengan objek, daerah, atau fenomena yang dikaji. Perekaman atau pengumpulan data penginderaan jauh dapat dilakukan dengan menggunakan sensor yang dipasang pada pesawat terbang atau satelit (Lillesand dan Kiefer, 1979).

Algoritma indeks vegetasi Normalized Difference Vegetation Indeks (NDVI) dan Enhanched Vegetation Indeks (EVI) untuk melakukan identifikasi fenologi tanaman padi dan perbedaan dua algoritma dalam mendefenisi tahapan fenologi tanaman. Pola tanam hasil algoritma NDVI dan EVI disesuaikan dengan estimasi pola tanam berdasarkan data klimatologi untuk mengetahui kondisi 
ketersediaan air tanaman padi sawah. Penelitian ini bertujuan untuk mengetahui pola tanam dan kalender tanam yang tepat di daerah irigasi Batang Anai berdasarkan interpretasi citra Landsat 8 dan kondisi iklim setempat.

\section{METODOLOGI PENELITIAN}

\section{A. Waktu dan Tempat}

Penelitian dilaksanakan mulai dari bulan Februari 2020 sampai dengan bulan April 2020. Penelitian ini dilakukan di daerah irigasi Batang Anai Kabupaten Padang Pariaman dan dianalisis di Laboratorium Teknik Sumberdaya Air dan Lahan Pertanian Jurusan Teknik Pertanian Universitas Andalas Padang.

\section{B. Alat dan Bahan}

Alat yang digunakan dalam penelitian ini adalah perangkat keras berupa seperangkat komputer, dan perangkat lunak seperti; ArcGis 10.5, Global Mapper 12 dan Microsoft Office, Global Positioning System (GPS), Digital Camera dan penyimpan data (hardisk eksternal). Bahan yang dibutuhkan dalam pelaksanaan penelitian ini terdiri dari: (1) data citra Landsat 8 Operation Land Imager (OLI)/Thermal Infra Red Sensor (TIRS) tahun 2014-2019, (2) data Rencana Tata Ruang Wilayah (RTRW) Kabupaten Padang Pariaman, (3) data pertanian lahan basah (sawah eksisting), (4) data Daerah Irigasi (DI), dan (5) data klimatologi.

\section{Pelaksanaan Penelitian}

Penelitian dilakukan beberapa tahapan yaitu: (1) pengumpulan data, (2) pengolahan data spasial, (3) analisis curah hujan, (4) analisis kebutuhan air irigasi, dan (5) analisis pola tanam dan kalender tanam padi sawah. Sistematika pelaksanaan penelitian dapat dilihat pada diagram alir pada Gambar 1.

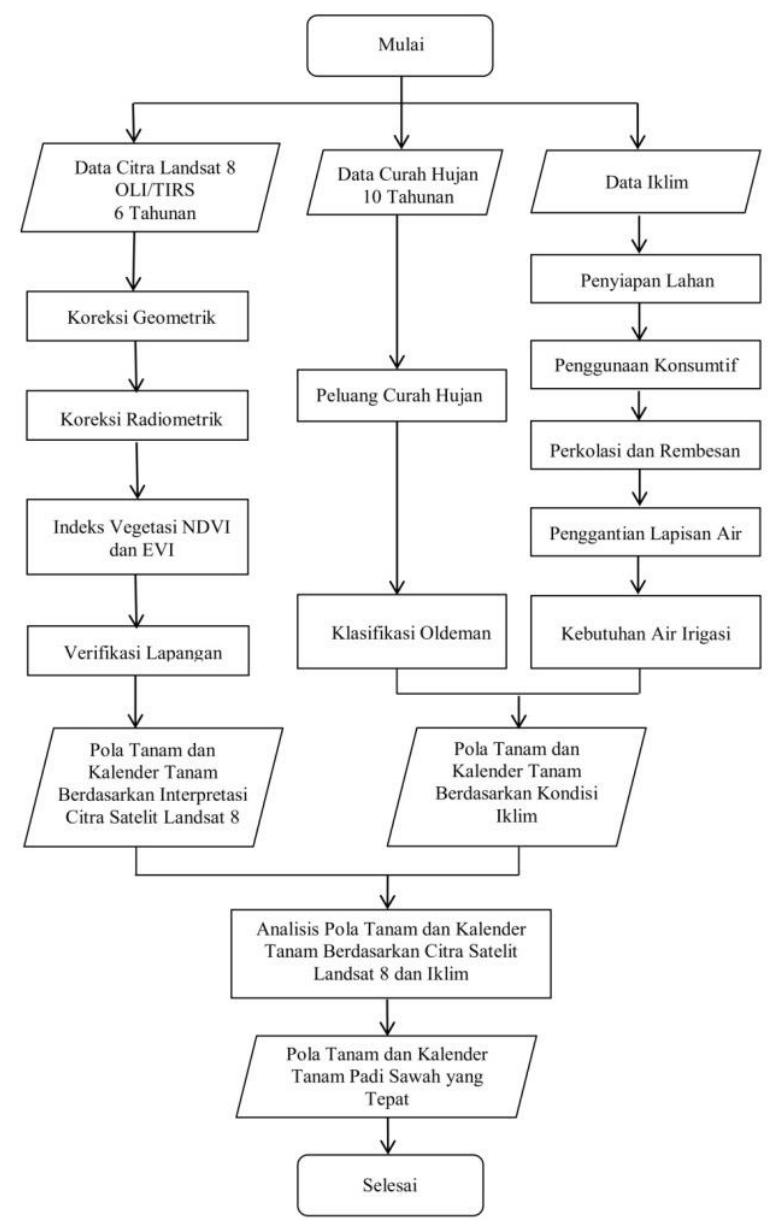

Gambar 1. Diagram Alir Penelitian 


\section{Pengumpulan Data}

Data-data yang diperlukan dalam pelaksanaan penelitian ini terdiri dari: (1) data citra Landsat 8 OLI/TIRS tahun 2014-2019 dari United State Geological Survey (USGS), (2) data RTRW Kabupaten Padang Pariaman dari Dinas PUPR, (3) data pertanian lahan basah (sawah eksisting) dari Dinas Pertanian dan Ketahanan Pangan Kabupaten Padang Pariaman, (4) data Daerah irigasi (DI) dari Dinas Pengelolaan Sumberdaya Air (PSDA) Provinsi Sumatera Barat, dan (5) data klimatologi dari Stasiun Badan Meteorologi. Klimatologi dan Geofisika (BMKG) Sicincin.

\section{E. Pengolahan Data Spasial}

Tahapan pengolahan data terdiri dari beberapa proses yaitu: (1) Cropping Lokasi Penelitian. 2) Koreksi Geometrik dan Koreksi Radiometrik, (3) Analisis Normalized Difference Vegetation Indeks (NDVI) dan Enhanched Vegetation Indeks (EVI). Untuk mengetahui nilai reflektan band digunakan Persamaan (1) dan perhitungan koreksi atmosfer digunakan Persamaan (2) (USGS, 2019).

$\rho \lambda^{\prime}=M_{\rho} \times Q_{\text {cal }}+A_{\rho}$

keterangan :

$\rho \lambda^{\prime} \quad=$ Spectral Reflectance;

$\mathrm{M}_{\rho} \quad$ = faktor skala multiplikasi reflektan pada band;

$\mathrm{A}_{\rho} \quad=$ faktor skala aditif reflektan pada band; dan

$\mathrm{Q}_{\mathrm{cal}} \quad=$ nilai digital number

$\rho \lambda=\frac{\rho \lambda^{\prime}}{\cos (\theta S Z)}=\frac{\rho \lambda^{\prime}}{\sin (\theta S E)}$

keterangan :

$\rho \lambda \quad=$ Top of Atmosphere Reflectance;

$\theta_{\mathrm{SE}} \quad=$ sudut ketinggian matahari lokal; dan

$\theta_{\mathrm{SZ}} \quad=$ sudut zenith matahari lokal. $\left(\theta_{\mathrm{SZ}}=90^{\circ}-\theta_{\mathrm{SE}}\right)$

Upaya untuk mengkarakterisasi tahap-tahap fenologi padi sawah dengan menggunakan indeks vegetasi NDVI menggunakan Persamaan (3) dan EVI dengan Persamaaan (4) (Lonita et al., 2015).

$\mathrm{NDVI}=\frac{\rho N I R-\rho \text { red }}{\rho N I R+\rho \text { red }}$

keterangan :

NDVI = Normalized Difference Vegetation Indeks;

$\rho N I R=$ reflaktansi permukaan kanal NIR; dan

pred = reflaktansi permukaan kanal merah.

$\mathrm{EVI}=G \times \frac{\rho \mathrm{NIR}-\rho \text { red }}{\rho N I R+C 1 \times \rho \text { red }-C 2 \times \rho \text { blue }+L}$

keterangan :

EVI = Enhanched Vegetation Indeks;

$L \quad=$ faktor kalibrasi dari efek kanopi dan tanah $(\mathrm{L}=1)$;

C1. $C 2$ = koefisien aerosol $(\mathrm{C} 1=6.0 . \mathrm{C} 2=7.5)$;

$G \quad=$ gain faktor $(\mathrm{G}=2.5)$;

$\rho N I R=$ reflaktansi permukaan kanal NIR;

pred = reflaktansi permukaan kanal merah; dan

pblue $=$ reflaktansi permukaan kanal biru .

Tahap fenologi atau fase pertumbuhan tanaman merupakan dasar untuk mengetahui umur tanaman padi. Umur tanaman padi dan varietas padi menjadi acuan dalam menentukan pola tanam dan kalender tanam padi. Koreksi umur tanam padi dilakukan tinjauan lapangan di 20 titik ground truth yang dapat mewakili sebaran lahan sawah di daerah irigasi Batang Anai.

\section{F. Analisis Curah Hujan}

Analisis peluang curah hujan ditetapkan dengan kemungkinan kajadian $80 \%$, artinya curah hujan yang besarnya dapat dilampaui sebanyak $80 \%$ atau dengan kata lain dilampauinya 8 kali 
kejadian dari 10 kali kejadian, ditentukan dengan menggunakan metode probabilitas weilbul pada Persamaan (5) (Asdak, 2010).

$R_{80}=\frac{m}{(n+1)}$------------m $=R_{80} x(n+1)$

keterangan :

$\mathrm{R}_{80}=$ curah hujan sebesar $80 \%$;

$n \quad$ = Jumlah data; dan

$m \quad$ = rangking curah hujan yang dipilih.

Curah hujan efektif untuk padi adalah $70 \%$ dari curah hujan tengah bulanan yang terlampaui $80 \%$ dari waktu periode $\mathrm{R}_{80}$, dikaitkan dengan nilai evapotranpirasi tanaman rata-rata bulanan dan curah hujan rata-rata bulanan, ditentukan dengan Persamaan (6).

$R e_{\text {padi }}=\left(R_{80} \times 0.7\right)$

keterangan :

$\operatorname{Re} \quad=$ curah hujan efektif ( $\mathrm{mm} / \mathrm{hari})$ :

$R_{80} \quad=$ curah hujan dengan kemungkinan terjadi sebesar $80 \%$.

Tipe iklim ditentukan berdasarkan klasifikasi Oldeman dengan menetapkan periode bulan basah (bulan dengan curah hujan >200) dan bulan kering (bulan dengan curah hujan $<100$ ) berturutturut (Tabel 1). Seterusnya diterjemahkan pada penjabaran pola tanam tipe agroklimat Oldeman (Tabel 2).

Tabel 1. Zona Agroklimat berdasarkan Klasifikasi Oldeman

\begin{tabular}{cccc}
\hline Tipe Utama & $\begin{array}{c}\text { Jumlah Bulan Basah } \\
\text { Berturut-turut }\end{array}$ & Sub Divisi & $\begin{array}{c}\text { Jumlah Bulan Kering } \\
\text { Berturut-turut }\end{array}$ \\
\hline A & 9 & 1 & $<2$ \\
B & $7-9$ & 2 & $2-3$ \\
C & $5-6$ & 3 & $4-6$ \\
D & $3-4$ & 4 & $>6$ \\
E & $<3$ & & \\
\hline
\end{tabular}

Sumber: Prastowo (2010)

Tabel 2. Penjabaran Tipe Agroklimat Menurut Oldeman

\begin{tabular}{cl}
\hline Tipe Agroklimat & \multicolumn{1}{c}{ Penjelasan } \\
\hline A1. A2 & $\begin{array}{l}\text { sesuai untuk padi terus menerus tetapi produksi kurang karena pada } \\
\text { umumnya kerapatan fluks radiasi surya rendah sepanjang tahun } \\
\text { sesuai untuk padi terus menerus dengan perencanaan awal musim tanam } \\
\text { yang baik. produksi tinggi bila panen pada kemarau } \\
\text { dapat tanam padi dua kali setahun dengan varietas umur pendek dan } \\
\text { musim kering yang pendek cukup untuk tanaman palawija } \\
\text { tanaman padi dapat sekali dan palawija dua kali setahun } \\
\text { setahun hanya dapat satu kali padi dan penanaman palawija yang kedua } \\
\text { harus hati-hati jangan jatuh pada bulan kering } \\
\text { tanam padi umur pendek satu kali dan biasanya produksi bisa tinggi } \\
\text { karena fluks radiasi tinggi. waktu tanam palawija cukup } \\
\text { hanya mungkin satu kali padi atau satu kali palawija setahun. tergantung } \\
\text { pada adanya persediaan air irigasi } \\
\text { daerah ini umumnya terlalu kering. mungkin hanya dapat dapat satu kali } \\
\text { palawija. itupun tergantung adanya hujan }\end{array}$ \\
C2. C3. C4 &
\end{tabular}

Sumber: Prastowo (2010)

\section{G. Kebutuhan Air Irigasi}

Kebutuhan air irigasi dapat diketahui dengan menentukan curah hujan efektif dan kemudian dikurangi dengan kebutuhan air di sawah untuk padi. Kebutuhan air di sawah untuk padi merupakan akumulasi air yang dibutuhkan tanaman padi selama fase pertumbuhan dan storage lahan. 
1. Penyiapan Lahan

Kebutuhan air untuk penyiapan lahan sawah ditentukan oleh kondisi fisik tanah, kemiringan lahan, storage air tanah dan lama waktu pengolahan tanah. Metode yang digunakan yaitu metode yang dikembangkan oleh Van de Goor dan Zijlstra (1968), yang ditentukan menggunakan Persamaan (7) sampai dengan Persamaan (10).

$I R=\frac{M x e^{k}}{e^{k}-1}$

keterangan :

IR = kebutuhan air untuk penyiapan lahan ( $\mathrm{mm} / \mathrm{hari})$;

$\mathrm{M} \quad=$ kehilangan air akibat evaporasi dan perkolasi $(\mathrm{mm} / \mathrm{hari})$;

$e \quad=$ bilangan natural; 2,7182; dan

$\mathrm{k} \quad=$ koefisien penggantian air di sawah;

$M=E_{0}+P$

keterangan :

$\mathrm{E}_{0} \quad=$ evaporasi air terbuka selama penyiapan lahan ( $\left.\mathrm{mm} / \mathrm{hari}\right) ;$ dan

$\mathrm{P} \quad=$ perkolasi $(\mathrm{mm} / \mathrm{hari})$;

$E_{0}=0,129\left(e_{s}-e_{a}\right) U 2$

keterangan :

U2 = kecepatan angin (m/detik);

$\mathrm{e}_{\mathrm{s}} \quad=$ tekanan uap jenuh $(\mathrm{mm} \mathrm{Hg})$; dan

$\mathrm{e}_{\mathrm{a}} \quad=$ tekanan udara $(\mathrm{mm} \mathrm{Hg})$.

$\mathrm{k}=\frac{M \times T}{S}$

keterangan :

$\mathrm{T}=$ jangka waktu penyiapan lahan (hari); dan

$\mathrm{S} \quad=$ kebutuhan air untuk penjenuhan $(\mathrm{mm}) ; 300 \mathrm{~mm}$.

2. Penggunaan Konsumtif

Jumlah air konsumtif tanaman padi dihitung menggunakan Persamaan (11), nilai koefisien tanaman padi pada Tabel 3 .

$E T_{c}=K_{c} x E T_{0}$

keterangan :

$E T_{c} \quad=$ evapotranspirasi tanaman $(\mathrm{mm} / \mathrm{hari})$;

$K_{c} \quad=$ koefisien tanaman; dan

$E T_{0} \quad=$ evapotranspirasi tanaman acuan (mm/hari).

Tabel 3. Koefisien Tanaman Padi $\left(K_{c}\right)$

\begin{tabular}{ccccc}
\hline \multirow{2}{*}{ Bulan } & \multicolumn{2}{c}{ Nedeco/Prosida } & \multicolumn{2}{c}{ FAO } \\
\cline { 2 - 5 } & Varietas Biasa & Varietas Unggul & Varietas Biasa & Varietas Unggul \\
\hline 0,5 & 1,2 & 1,2 & 1,1 & 1,1 \\
1 & 1,2 & 1,27 & 1,1 & 1,1 \\
1,5 & 1,32 & 1,33 & 1,1 & 1,05 \\
2 & 1,4 & 1,3 & 1,1 & 1,05 \\
2,5 & 1,35 & 1,15 & 1,1 & 0,95 \\
3 & 1,24 & 0 & 1,05 & 0 \\
3,5 & 1,12 & & 0,95 & \\
4 & 0 & & 0 & \\
\hline
\end{tabular}

Sumber : KP-01 (2013)

Nilai evapotranspirasi tanaman acuan $\left(E T_{0}\right)$ digunakan persamaan standar FAO yang dikembangkan untuk menghitung evapotranspirasi tanaman acuan berdasarkan Penman Monteith (1965), persamaan matematis pada Persamaan (12) sampai dengan Persamaan (18). 
$E T_{0}=\frac{\left\{\left(\delta-R_{n} / L\right)\right\}+\tau\left\{\left(900 / T_{k}\right) U_{2}\left(e_{S}-e_{a}\right)\right\}}{\delta+\tau\left(1+0,34 . U_{2}\right)}$

keterangan :

$E T_{0} \quad=$ evapotranspirasi tanaman acuan (mm/hari);

$\delta \quad=$ kemiringan kurva tekanan uap terhadap temperatur $\left(\mathrm{kPa} /{ }^{\circ} \mathrm{C}\right)$;

$R_{n} \quad=$ radiasi bersih $\left(\mathrm{MJ} / \mathrm{m}^{2} /\right.$ hari $)$

$L \quad=$ panas laten untuk penguapan $(\mathrm{MJ} / \mathrm{kg})$;

$\tau \quad=$ konstanta psikometrik $=0,06466 \mathrm{kPa} /{ }^{\circ} \mathrm{C}$;

$T_{k} \quad=$ temperatur udara $\left({ }^{0} \mathrm{~K}\right)$;

$U_{2} \quad=$ kecapatan angin pada tinggi $2 \mathrm{~m}$ (meter/detik);

$e_{a} \quad=$ tekanan uap aktual $(\mathrm{kPa})$; dan

$e_{s} \quad=$ tekanan uap jenuh $(\mathrm{kPa})$.

$R_{n}=R_{a}(1-\alpha)(0,25+0,50 n / N)-\beta T_{k}^{4}(0,34-0,14 \sqrt{e s})(0,10+0,90 n / N)$

keterangan :

$\mathrm{R}_{\mathrm{a}} \quad=$ radiasi ekstra teresterial ( $\left.\mathrm{mm} / \mathrm{hari}\right)$;

$\alpha \quad=$ albedo (standard $\mathrm{FAO}=23 \%$ );

$\mathrm{n} / \mathrm{N} \quad=$ durasi penyinaran matahari relatif $(\%) ;$

$\beta=$ konstanta Stefan-Boltzman $\left(4,90 \times 10^{-9} \mathrm{MJ} / \mathrm{m}^{2} / \mathrm{K}^{-4} /\right.$ hari $)$;

$n / N=1-0,054 H^{0,42}$

keterangan :

$H \quad=$ curah hujan $(\mathrm{mm})$.

$e_{s}=0,611 . \exp [(17,27 T) /(T+237,3)]$

dimana :

$T \quad=$ temperatur udara $\left({ }^{0} \mathrm{C}\right)$.

$e_{a}=e_{s} \times R H$

keterangan :

RH = kelembaban relatif $(\%)$

$\delta=\left(4.089 \times e_{s}\right) /(T+237,3)^{2}$

$L=2,501-\left(2,361 \times 10^{-3}\right) T$

3. Perkolasi dan Rembesan

Laju perkolasi sangat tergantung pada sifat fisik tanah, pada tanah lempung berat dengan karakteristik pengelolaan (puddling) yang baik, laju perkolasi dapat mencapai $1-3 \mathrm{~mm} / \mathrm{hari}$. Pada tanah yang lebih ringan, laju perkolasi bisa menjadi lebih tinggi. Nilai perkolasi dari berbagai jenis tanah dapat dilihat pada Tabel 4.

Tabel 4. Nilai Perkolasi dari berbagai Jenis Tanah

\begin{tabular}{ccc}
\hline No. & Jenis Tanah & Nilai Perkolasi $(\mathrm{mm} / \mathrm{hari})$ \\
\hline 1 & Sandy loam & $3-6$ \\
2 & Loam & $2-3$ \\
3 & Clay & $1-2$ \\
\hline
\end{tabular}

Sumber: Soemarto (1987)

4. Penggantian Lapisan Air

Setelah pemupukan pada padi sawah biasanya dijadwalkan untuk mengganti lapisan air sesuai dengan kebutuhan, penggantian dilakukan sebanyak 2 kali (2 bulan) masing-masing $50 \mathrm{~mm}(3,3$ $\mathrm{mm} /$ hari selama 15 hari setiap bulan) selama sebulan dan dua bulan setelah transplantasi (KP-01, 2013). 
Kondisi curah hujan dan kebutuhan air irigasi merupakan acuan untuk menentukan pola tanam dan kalender tanam di daerah irigasi Batang Anai. Karamouz et al., (2010) menyatakan bahwa pola tanam dari suatu lahan pertanian dapat dioptimalkan sesuai dengan ketersediaan air di wilayah tersebut.

\section{H. Pola Tanam dan Kalender Tanam Padi Sawah}

Pola tanam dan kalender tanam yang tepat di daerah irigasi Batang Anai ditentukan dengan menyandingkan atau menyesuaikan pola tanam dan kalender tanam hasil interpretasi citra Landsat 8 dengan pola tanam dan kalender tanam berdasarkan kondisi iklim. Pola tanam dan kalender tanam interpretasi citra Landsat 8 menggambarkan kebiasaan masyarakat setempat dan pola tanam dan kalender tanam sesuai kondisi iklim merupakan hasil pertimbangan ketersediaan air dengan kebutuhan air untuk mendukung pertumbuhan tanaman padi.

\section{HASIL DAN PEMBAHASAN}

\section{A. Gambaran Umum Lokasi}

Daerah Irigasi (DI) Batang Anai berada di dalam administrasi Kabupaten Padang Pariaman. secara geografis terletak antara $100^{\circ} 7^{\prime}$ 52" Bujur Timur dan $0^{\circ} 37^{\prime}$ 26" Lintang Selatan. Daerah terlayani oleh DI Batang Anai mencakup beberapa kecamatan yaitu; Kecamatan Batang Anai, Kecamatan Lubuk Alung, Kecamatan Sintuk Toboh Gadang, Kecamatan Ulakan Tapakis dan Kecamatan Nan Sabaris.

Luas daerah irigasi Batang Anai adalah 13.604 ha, terbagi menjadi 2 tahap pembangunan, tahap I memiliki luas daerah irigasi 6.840 ha dan tahap II memiliki luas 6.764 ha dengan luas lahan fungsional sawah (sawah eksisting) adalah 6.927 ha (PSDA Sumbar, 2019). Sumber air DI Batang Anai berasal dari sungai Batang Anai dan Outlet Pembangkit Listrik Tenaga Air (PLTA) Danau Singkarak, daerah irigasi Batang Anai secara visual dapat dilihat pada Gambar 2.

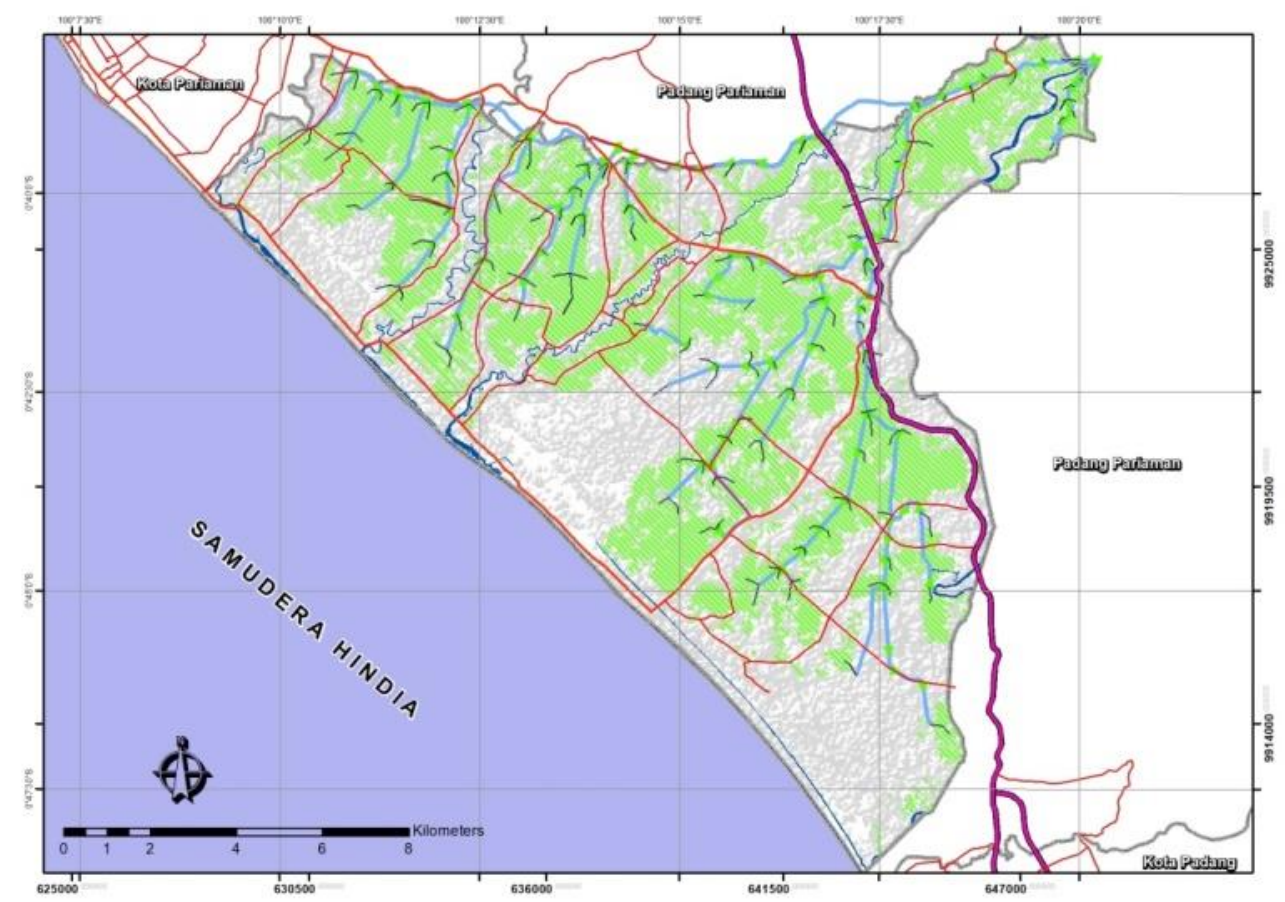

Gambar 2. Daerah Irigasi Batang Anai Kabupaten Padang Pariaman Sumber: Data PSDA Provinsi Sumatera Barat (2019)

\section{B. Pola Tanam dan Kalender Tanam Padi berdasarkan Nilai NDVI dan EVI}

Pola tanam dan kalender tanam berdasarkan nilai NDVI dan EVI merupakan interpretasi data citra Landsat 8 dikonversi menjadi nilai indeks vegetasi yang akan menjadi acuan untuk mengetahui umur tanam padi. Prediksi umur tanam padi akan disesuaikan dengan varietas padi untuk mengetahui 
awal musim tanam di daerah irigasi Batang Anai. Wahyunto et al., (2006) menyatakan bahwa nilai algoritma NDVI berkisar antara -1 hingga +1 , dimana nilai (-) menunjukkan objek air atau lahan bera dan basah dan nilai (+) menunjukkan objek vegetasi. Untuk tanaman padi sawah, NDVI baru dapat diukur setelah tanaman padi mencapai umur 3-4 MST (Minggu Setelah Tanam), karena sebelum umur tersebut kenampakan tanaman padi di lahan sawah masih didominasi kenampakan genangan air (Malingreau, 1981). Hubungan nilai NDVI terhadap tingkat pertumbuhan tanaman padi dapat dilihat pada Tabel 5.

Tabel 5 Hubungan Nilai NDVI terhadap Pertumbuhan Tanaman Padi

\begin{tabular}{ccccc}
\hline No & \multicolumn{2}{c}{ Rentang NDVI } & Tingkat Kehijauan & Umur Tanam (MST) \\
\hline 1 & 0,0169 & 0,1354 & Tidak bervegetasi/terbuka/air & $<3$ \\
2 & 0,1354 & 0,2540 & Kehijauan sangat rendah & $3-6$ \\
3 & 0,2540 & 0,3725 & Kehijauan rendah & $6-8$ \\
4 & 0,3725 & 0,4910 & Kehijauan sedang & $8-10$ \\
5 & 0,4910 & 0,6095 & Kehijauan tinggi & $10-13$ \\
\hline
\end{tabular}

Setelah vegetatif optimum nilai NDVI akan turun sesuai dengan tingkat kematangan bulir padi

Hasil interpretasi citra Landsat 8 selama 6 tahun diketahui nilai indeks vegetasi NDVI pada rentang minimum pada angka 0,0169 dan maksimum pada angka 0,6095. Nilai minimum diartikan kondisi tidak bervegetasi. atau lahan terbuka maupun berupa permukaan air yang diperkirakan padi kecil dari 3 minggu. Nilai maksimum menggambarkan kondisi permukaan dengan tingkat kehijauan tinggi yakni sekitar umur 10-13 minggu setelah tanam (vegetasi lebat), pada tahap ini vegetasi padi berada pada akhir fase vegetatif dan masuk fase pematangan bulir. Hubungan nilai EVI terhadap tingkat pertumbuhan tanaman padi dapat dilihat pada Tabel 6.

Tabel 6 Hubungan Nilai EVI terhadap Pertumbuhan Tanaman Padi

\begin{tabular}{ccccc}
\hline No & \multicolumn{2}{c}{ Rentang EVI } & Tingkat Kehijauan & Umur Tanam (MST) \\
\hline 1 & 0,1790 & 0,2787 & Tidak bervegetasi/terbuka/air & $<3$ \\
2 & 0,2787 & 0,3785 & Kehijauan sangat rendah & $3-6$ \\
3 & 0,3785 & 0,4782 & Kehijauan rendah & $6-8$ \\
4 & 0,4782 & 0,5779 & Kehijauan sedang & $8-10$ \\
5 & 0,5779 & 0,6777 & Kehijauan tinggi & $10-13$ \\
\hline
\end{tabular}

Setelah vegetatif optimum nilai EVI akan turun sesuai dengan tingkat kematangan bulir padi

Hasil interpretasi citra Landsat 8 selama 6 tahun diketahui nilai indeks vegetasi EVI pada rentang minimum pada angka 0,1790 dan maksimum pada angka 0,6777 . Perbedaan nilai yang didapatkan disebabkan oleh parameter algoritma, dimana algoritma NDVI mempertimbangkan nilai kanal merah (band red) dan kanal inframerah dekat (band NIR), sedangkan algoritma EVI selain kanal merah dan kanal inframerah dekat turut memperhitungkan pengaruh dari kanal biru (band biru). EVI merupakan peningkatan dari algoritma sebelumnya yaitu NDVI (Normalized Difference Vegetation Indeks). Algoritma NDVI sensitif terhadap saluran band merah yang menyerap kanopi dan memiliki kedalaman penetrasi optik yang lebih rendah di kanopi, dengan demikian akan lebih cepat menyerap di daerah biomassa tinggi, sedangkan EVI peka terhadap pita NIR pada jumlah vegetasi sedang hingga tinggi dengan penetrasi kedalaman optik yang lebih besar ke dalam kanopi (Gao et al., 2000). Grafik rata-rata 6 tahunan nilai indeks vegetasi NDVI dan EVI berdasarkan interpretasi citra Landsat 8 dilihat pada Gambar 3.

Berdasarkan Gambar 3. pola umur tanam padi terlihat tidak beraturan, hal ini disebabkan oleh tangkapan citra satelit yang tutupan awan. sehingga terdefinisi nilai indeks awan. bukan vegetasi yang berada di permukaan bumi. Nilai maksimum indeks vegetasi NDVI dan EVI diketahui terjadi pada akhir bulan April dan awal bulan Oktober. Umur tanaman padi yang tercermin dari nilai indeks vegetasi dan varietas padi dijadikan patokan untuk memprediksi awal musim tanam. Umur tanaman padi mengacu pada umur tanam padi 4 bulan, sebab di daerah irigasi Batang Anai rata-rata menanam padi varietas Cisokan yang memiliki umur tanam 110-120 hari. Secara visual pola tanam dan kalender tanam berdasarkan interpretasi citra Landsat 8 dilihat pada Gambar 4. 


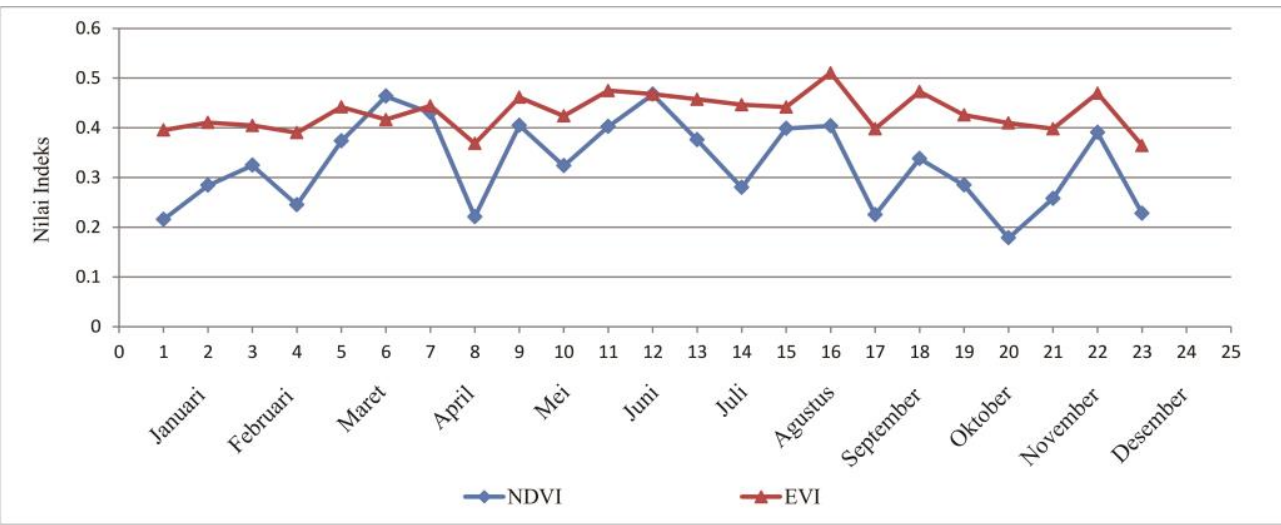

Gambar 3. Grafik Rata-rata 6 Tahunan Nilai Indeks Vegetasi NDVI dan EVI

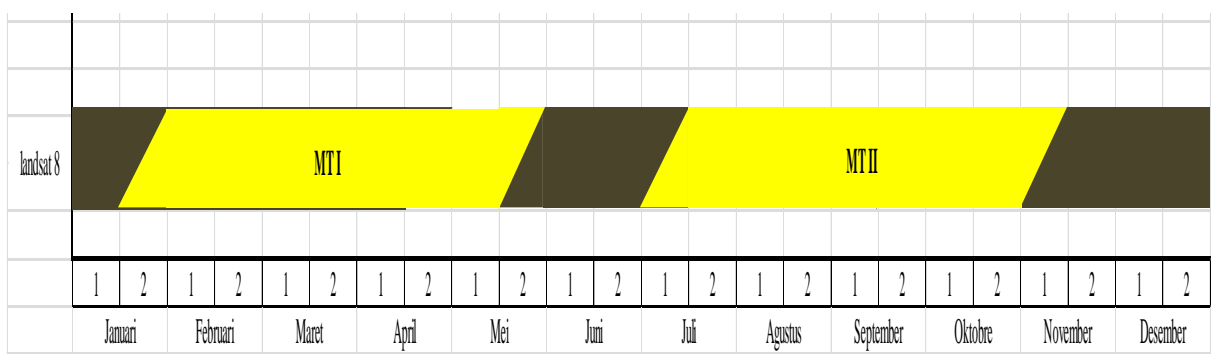

Gambar 4. Pola Tanam dan Kalender Tanam berdasarkan Interpretasi Citra Landsat 8

Pengamatan hasil trend nilai indeks vegetasi NDVI dan EVI yang dianalisis ditetapkan ada 2 kali musim tanam yaitu padi - padi, penanaman musim tanam I pada awal tahun yaitu bulan Januari dan musim tanam II pada bulan Juli. Penetapkan musim tanam didasari dari ada dua titik dengan nilai indeks vegetasi tertinggi yang diprediksi sebagai fase vegetatif akhir yang mewakili setiap musim tanam. Wahyunto et al., (2006) menyatakan bahwa setelah vegetatif optimum nilai indeks vegetasi akan turun sesuai dengan tingkat kematangan bulir padi.

\section{Pola Tanam dan Kalender Tanam Padi berdasarkan Kondisi Klimatologi \\ 1. Curah Hujan Efektif Padi}

Pada daerah irigasi Batang Anai terdapat 3 stasiun pengamatan curah hujan yang dapat mewakili kondisi iklim di wilayah DI Batang Anai, stasiun tersebut antara lain: Stasiun Bandara Internasional Minangkabau (BIM), Stasiun Lubuk Napar dan Stasiun Kasang. Kondisi curah hujan di daerah irigasi Batang Anai dapat dilihat pada Gambar 5.

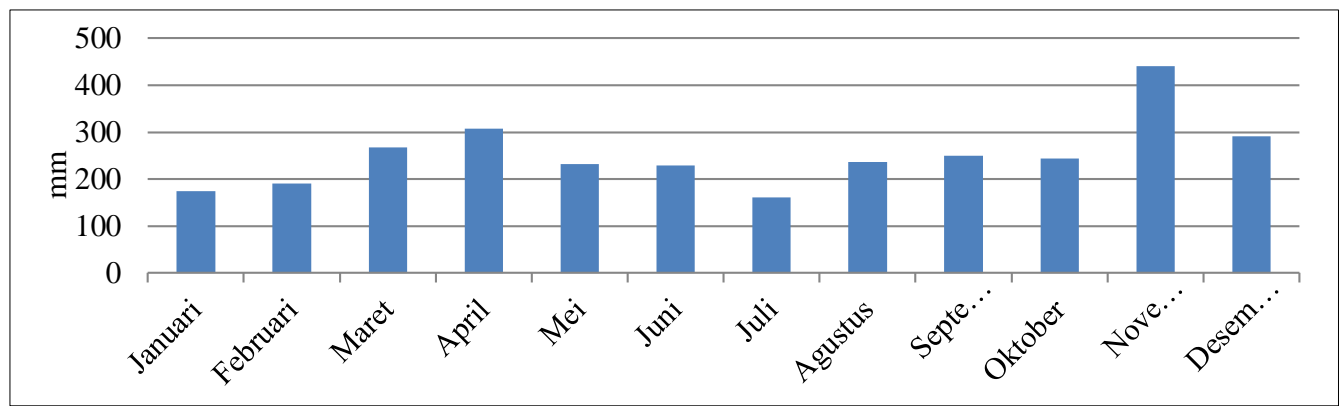

Gambar 5. Curah Hujan di Daerah Irigasi Batang Anai

Berdasarkan Gambar 4. curah hujan tertinggi terjadi pada bulan November sedangkan curah hujan terendah terjadi pada bulan Juli. Menurut klasifikasi Oldeman daerah irigasi Batang Anai termasuk ke dalam tipe iklim A1, karena berdasarkan data curah hujan DI Batang Anai memiliki bulan basah (curah hujan >200) 9 bulan dan bulan kering (curah hujan <100) 0 bulan. Tipe iklim A1 adalah daerah yang sesuai untuk padi terus menerus akan tetapi produksi kurang karena pada umumnya kerapatan fluk radiasi surya rendah sepanjang tahun. 


\section{Kebutuhan Air Irigasi Padi}

Kebutuhan air irigasi adalah akumulasi air yang dibutuhkan tanaman padi selama proses pertumbuhan di sawah, yang terdiri dari: kebutuhan air untuk penyiapan lahan, kebutuhan air konsumtif tanaman padi, kebutuhan perkolasi dan rembesan serta kebutuhan air untuk penggantian lapisan air, kebutuhan air irigasi di sawah dapat dilihat pada Tabel 7.

Tabel 7. Kebutuhan Air Irigasi di Sawah

\begin{tabular}{ccccccc}
\hline \multirow{2}{*}{ Bulan } & ETc/IR & Perkolasi & WLR & Re & IWR & NIWR \\
\cline { 2 - 7 } & $\mathrm{mm} / \mathrm{hari}$ & $\mathrm{mm} / \mathrm{hari}$ & $\mathrm{mm} / \mathrm{hari}$ & $\mathrm{mm} / \mathrm{hari}$ & $\mathrm{mm} / \mathrm{hari}$ & $\mathrm{mm} / \mathrm{hari}$ \\
\hline Januari & 11.64 & 3.00 & - & 3.92 & 10.72 & 16.54 \\
Februari & 4.74 & 3.00 & 1.72 & 4.62 & 4.84 & 7.47 \\
Maret & 5.29 & 3.00 & 1.61 & 6.04 & 3.86 & 5.96 \\
April & 5.08 & 3.00 & - & 7.17 & 0.91 & 1.41 \\
Mei & 4.68 & 3.00 & - & 5.25 & 2.43 & 3.75 \\
Juni & 11.66 & 3.00 & - & 5.34 & 9.31 & 14.37 \\
Juli & 5.02 & 3.00 & 1.61 & 3.65 & 5.98 & 9.23 \\
Agustus & 4.97 & 3.00 & 1.61 & 5.35 & 4.23 & 6.53 \\
September & 4.65 & 3.00 & - & 5.83 & 1.82 & 2.81 \\
Oktober & 4.30 & 3.00 & - & 5.51 & 1.79 & 2.76 \\
November & 11.64 & 3.00 & - & 10.28 & 4.36 & 6.73 \\
Desember & 5.00 & 3.00 & 1.61 & 6.57 & 3.04 & 4.70 \\
\hline
\end{tabular}

Kebutuhan air irigasi tertinggi pada bulan Januari dan bulan Juli, ini disebabkan oleh selain dari kebutuhan air untuk penggunaan konsumtif, perkolasi dan rembesan serta penggantian lapisan air, pada bulan tersebut dibutuhkan juga air untuk pengolahan lahan. Kebutuhan air di sawah dijadikan acuan untuk menentukan kebutuhan air irigasi, yang ditentukan oleh beberapa faktor-faktor, yaitu: (1) penyiapan lahan, (2) penggunaan konsumtif, (3) perkolasi dan rembesan, (4) penggantian lapisan air, dan (5) curah hujan efektif (KP-01, 2013). Kondisi Keseimbangan Air (Water Balance) padi sawah di daerah irigasi Batang Anai dapat dilihat pada Gambar 6.

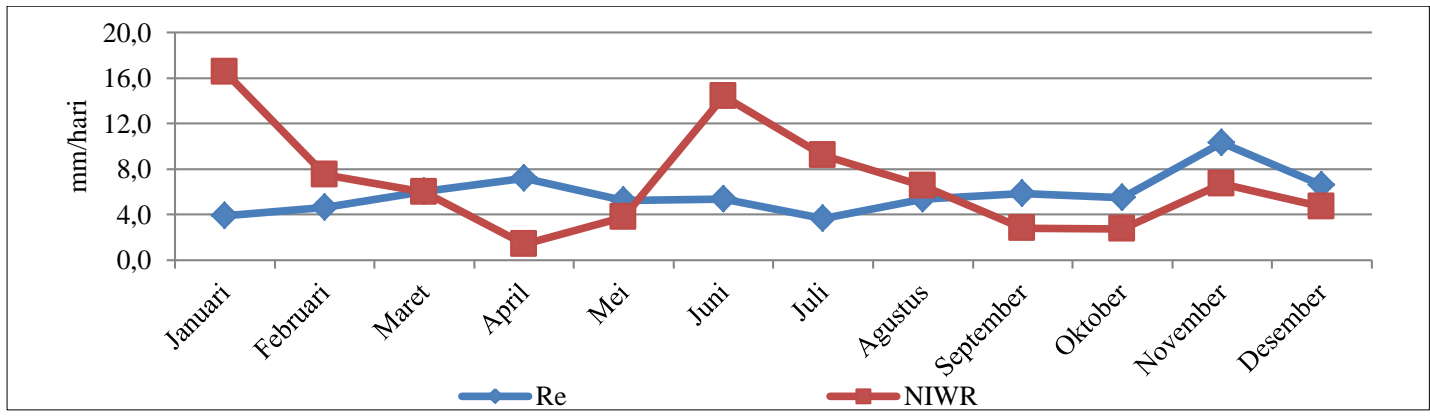

Gambar 6. Water Balance Padi Daerah Irigasi Batang Anai

Keseimbangan air pada lahan sawah di daerah irigasi Batang Anai menggambarkan kondisi kebutuhan dan ketersediaan air, kondisi ini merupakan acuan dalam menentukan awal musim tanam padi. Jika terjadi kekurangan air di sawah, maka dapat ditambahkan dari air irigasi Batang Anai. Runtunuwu et al., (2011) menyatakan bahwa lahan sawah tadah hujan dan lahan sawah irigasi, ketersediaan dan pasokan atau kebutuhan air berkaitan dengan penentuan awal musim tanam. Keragaman curah hujan yang tinggi secara spasial dan temporal serta distribusi curah hujan yang tidak seragam menjadi kendala dalam memutuskan awal tanam (Stewart, 1991).

\section{Pola Tanam dan Kalender Tanam Padi berdasarkan Iklim}

Berdasarkan hubungan curah hujan dan kebutuhan air irigasi di sawah pada daerah irigasi Batang Anai dapat diidentifikasi indeks pertanaman sebesar 2,5 kali dalam setahun dengan pola tanam Padi - Padi - Padi, musim tanam padi ke-3 (MT III) akan panen pada awal tahun berikutnya, sehingga 
selama 2 tahun penanaman padi di DI Batang Anai dapat dilakukan sebanyak 5 kali. Hal ini disebabkan oleh besar curah hujan yang terjadi setiap bulan dapat memenuhi kebutuhan air selama fase petumbuhan tanaman padi sawah. Secara visual pola tanam dan kalender tanam berdasarkan kondisi iklim di daerah irigasi Batang Anai dapat dilihat pada Gambar 7.

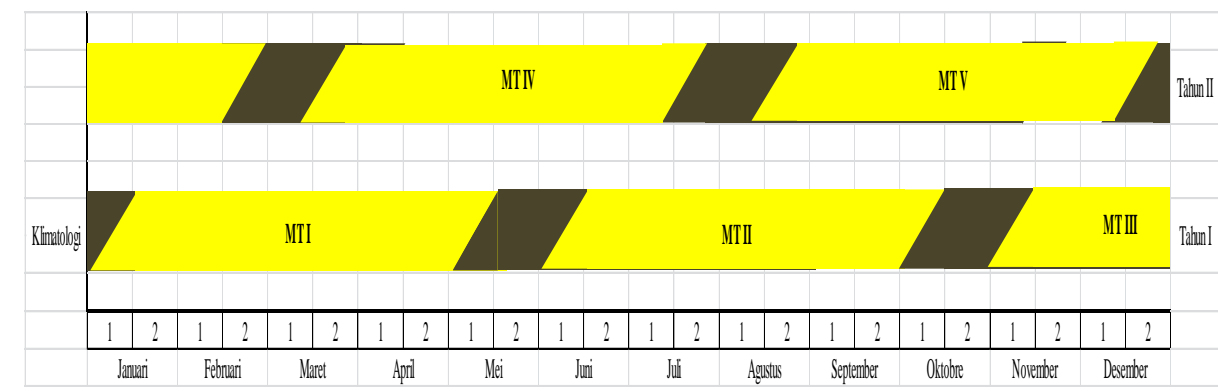

Gambar 7. Pola Tanam dan Kalender Tanam Berdasarkan Kondisi Iklim

Pola tanam dan kalender tanam yang direkomendasikan mengikuti kondisi klimatologi setempat, sebab kebutuhan air yang diperlukan untuk tanaman padi dapat dipenuhi dari curah hujan, jika terjadi kekurangan air dapat ditambahkan dari air irigasi dengan pengelolaan yang benar dan tepat. Sesuai fungsi irigasi yaitu dapat memberikan air untuk tanaman padi pada lokasi yang tepat, jumlah sesuai kebutuhan dan diberikan pada saat diperlukan. Salah satu upaya meningkatkan produksi padi dapat dilakukan intensifikasi, mengingat ketersedian air yang baik di daerah irigasi Batang Anai, sehingga dibutuhkan perencanaan pola tanam dan kalender tanam yang tepat. Suwarno (2010) menyatakan bahwa intensifikasi dilakukan dengan penerapan teknologi varietas dan teknik budidaya untuk meningkatkan produktivitas lahan, baik melalui peningkatan hasil per satuan luas maupun peningkatan intensitas tanam dari 1 kali menjadi 2 dan 3 kali tanam setiap tahun.

\section{Sebaran Pola Tanam dan Kalender Tanam di Daerah Irigasi Batang Anai}

Secara visual sebaran pola tanam dan kalender tanam di daerah irigasi Batang Anai berdasarkan interpretasi citra Landsat 8 time series 6 tahunan dapat dilihat pada Gambar 8 . Sebaran Musim Tanam (MT) padi sesuai dengan pola tanam dan kalender tanam hasil interpretasi citra Landsat 8 pada bulan Januari (MT I), Juni (MT II) dan November (MT III) di daerah irigasi Batang Anai.

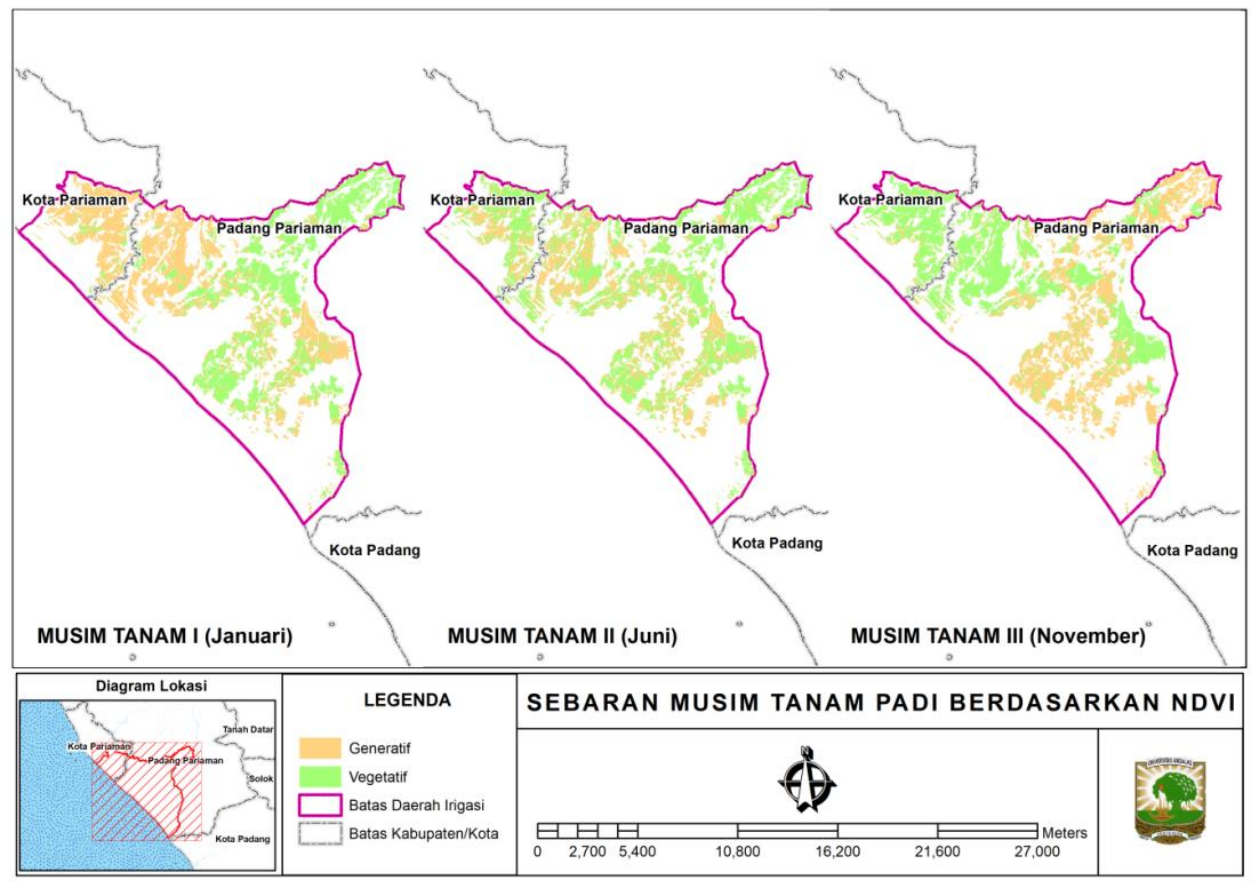

(a) Normalized Difference Vegetation Indeks (NDVI) 


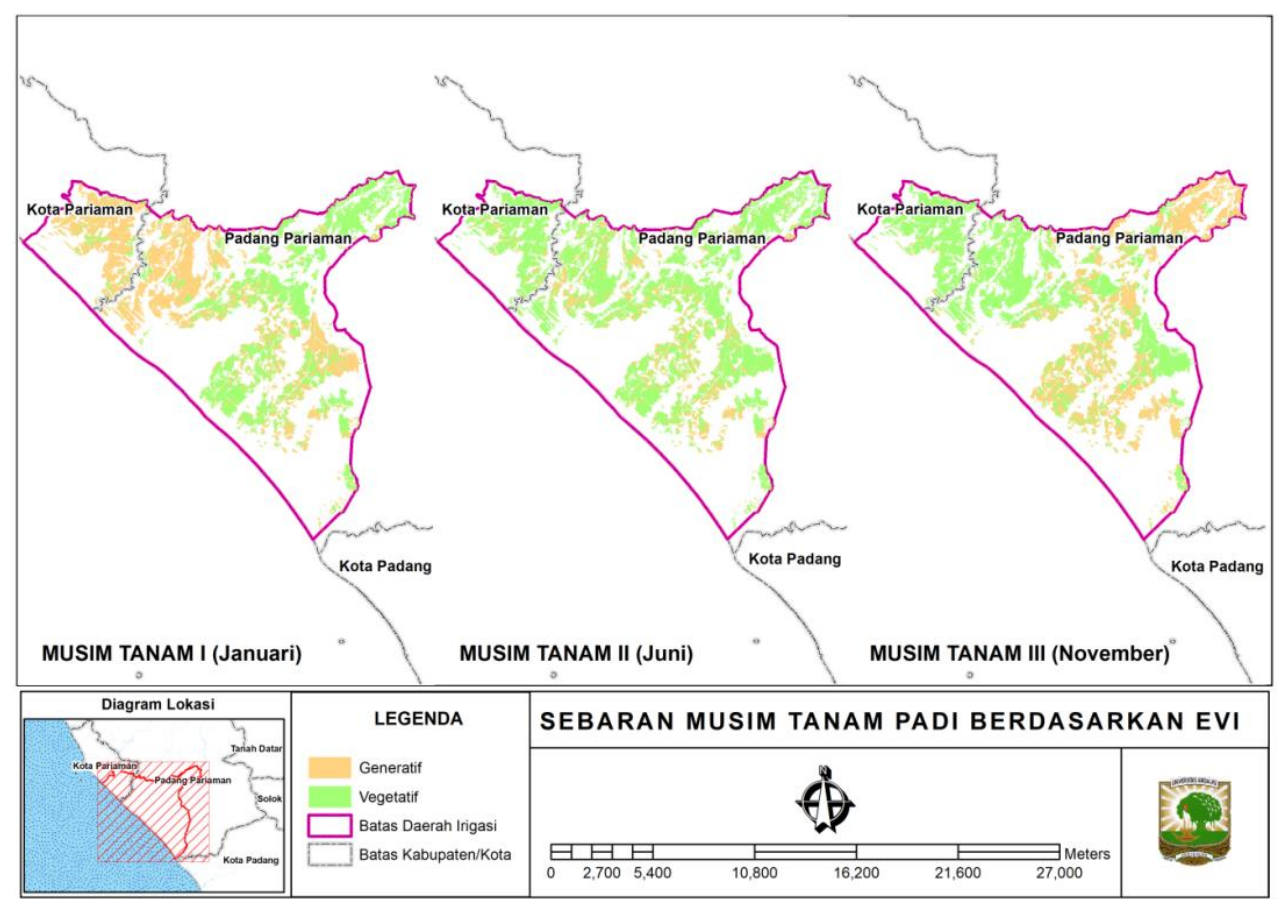

(b) Enhanched Vegetation Indeks (EVI)

Gambar 8. Sebaran Pola Tanam dan Kalender Tanam di Daerah Irigasi Batang Anai

Klasifikasi sebaran musim tanam padi dibagi menjadi 2, yaitu: fase vegetatif dan fase generatif, dimana fase vegetatif merupakan sebaran lahan sawah yang melakukan awal penanaman pada bulan Januari, Juni dan November, sedangkan fase generatif adalah sebaran lahan yang melakukan awal penanaman selain bulan Januari, Juni dan November. Luas sebaran musim tanam padi di daerah irigasi Batang Anai dilihat pada Tabel 8.

Tabel 8. Luas Sebaran Musin Tanam Padi di Daerah Irigasi Batang Anai

\begin{tabular}{cccccccc}
\hline \multirow{2}{*}{ No. } & \multirow{2}{*}{ Fese Pertumbuhan } & \multicolumn{2}{c}{ Musim Tanam I } & \multicolumn{2}{c}{ Musim Tanam II } & \multicolumn{2}{c}{ Musim Tanam III } \\
\cline { 2 - 7 } & & Ndvi & Evi & Ndvi & Evi & Ndvi & Evi \\
\hline 1 & Generatif & $3.669,58$ & $3.562,28$ & $2.732,10$ & $1.434,09$ & $3.203,53$ & $2.674,17$ \\
2 & Vegetatif & $3.085,08$ & $3.192,38$ & $4.022,56$ & $5.320,57$ & $3.551,13$ & $4.080,49$ \\
\hline
\end{tabular}

Berdasarkan Tabel 8, ada 2 fase pertumbuhan padi di daerah irigasi Batang Anai pada MT I (Januari), MT II (Juni) dan MT III (November) mengindikasi sesuai kenampakan citra Landsat 8 di lapangan petani belum melakukan penanaman padi secara serentak. Penanaman tidak serentak dapat disebabkan oleh prasarana dan sarana terbatas dan kurang tenaga kerja. Safitri dan Yulianto (2019) perbedaan jadwal tanam disebabkan oleh kondisi air kurang mencukupi, kondisi lahan tidak rata, sarana dan prasarana terbatas, kurang tenaga kerja dan petani mengejar waktu tanam berikutnya. Sebaran pola tanam dan kalender tanam berdasarkan interpretasi citra Landsat 8 dapat menjadi acuan, karena merupakan kebiasaan masyarakat setempat selama enam tahun dan didukung oleh ketersediaan air dari curah hujan dan air irigasi. Peluang intensifikasi dapat dilakukan dengan manajemen dan pengaturan pola tanam dan kalender tanam yang disepakati oleh pemerintah dan petani.

\section{KESIMPULAN}

Pola tanam interpretasi data citra Landsat 8 selama enam tahun dengan menggunakan algoritma NDVI dan EVI adalah 2 kali setahun, penanaman musim tanam I pada bulan Januari dan musim tanam II pada bulan Juli. Pola tanam berdasarkan kondisi klimatologi adalah 2,5 kali setahun, penanaman musim tanam I pada bulan Januari, musim tanam II pada bulan Juni dan musim tanam III pada bulan November. Musim tanam IV pada bulan Maret dan musim tanam V pada bulan Agustus tahun berikutnya. 


\section{DAFTAR PUSTAKA}

[Kemen PU] Kementerian Pekerjaan Umum. Direktorat Jenderal Sumber Daya Air. 2013. Standar Perencanaan Irigasi - Kriteria Perencanaan bagian Perencanaan Jaringan Irigasi KP-01. Jakarta: Direktorat Irigasi dan Rawa. 230 hal.

[PSDA] Pengelolaan Sumber Daya Air. 2019. Luas Daerah Irigasi Batang Anai. Padang: Dinas Pengelolaan Sumber Daya Air Provinsi Sumatera Barat.

Asdak C. 2010. Hidrologi dan Pengelolaan Daerah Aliran Sungai. Yogyakarta: Gadjah Mada University Press. 630 hal.

Gao F. Schaaf C. and Strahler A.H. 2000. Using a Multi Kernel Least Variance Approach to Retrieve and Evaluate Albedo from Limited BRDF Observations. Remote Sens Environ. 76. : 57-66. doi:10.1016/S0034-4257(00)00192-9

Karamouz M. Zahraie B. Kerachian R. and Eslami A. 2010. Crop pattern and conjunctive use management. A case study. Vol. 59 No. 2. : 161-173. doi:10.1002/ird.457

Lillesand T.M. dan Kiefer R.W. 1979. Remote Sensing and Image Interpretation. Numerous Illustrations. New York: John Wiley. 612 hal.

Lonita B.I. Prasetyo Y. dan Hani'ah. 2015. Analisis Perubahan Luas dan Kerapatan Hutan menggunakan Algoritma NDVI dan EVI pada Citra Landsat 7. Jurnal Geodesi. Universitas Diponegoro. Semarang. Vol. $4 . \quad$ No. $3 . \quad: \quad 112-120$. https://ejournal3.undip.ac.id/index.php/geodesi/article/view/8965

Malingreau J.P. 1981. Remote Sensing for Monitoring Rice Production in the Wet Tropics. Approach and Implication. Symposium on Application of Remote Sensing for Rice Production. Hyderabad. India.

Prastowo. 2010. Daya Dukung Lingkungan Aspek Sumberdaya Air. Working Paper No. 1. Bogor: Institut Pertanian Bogor. 20 hal. https://adoc.tips/download/daya-dukung-lingkungan-aspeksumberdaya-air.html

Rahma R.N. Rondhi M dan Suwandari A. 2018. Faktor-faktor yang Mempengaruhi Pola Tanam dan Pendapatan Petani pada berbagai Ketersediaan Air di Daerah Irigasi Karanglo. Jember: Seminar Nasional Universitas Jember. 03 November 2018. 6 hal. https://jurnal.unej.ac.id/index.php/prosiding/article/view/9020/6611

Rahmawati S. 2006. Status Perkembangan Perbaikan Sifat Genetik Padi Menggunakan Transformasi Agrobacterium. Jurnal AgroBiogen. Vol. 2. No. 1. : 36-44. doi:10.21082/jbio.v2n1.2006.p3644

Runtunuwu E. Syahbuddin H. Las I. and Amien I. 2011. Utilizing Cropping Calendar In Coping With Climate Change. Journal Ecolab. Vol. 5 No. 1. : 1-14. doi:10.20886/jklh.2011.5.1.1-14

Safitri H.M. dan Yulianto A.D. 2019. Dampak Masalah Jadwal Tanam Padi terhadap Perubahan Sosial Masyarakat di Desa Dukuhmencek Kecamatan Sukorambi Kabupaten Jember. Journal Agriecobis. Universitas Jember. Vol. 2 No. 1. : 1-13. doi:10.22219/agriecobis.

Soemarto C.D. 1987. Hidrologi Teknik. Surabaya: Usaha Nasional. 511 hal.

Soewarno. 2010. Meningkatkan Produksi Padi Menuju Ketahanan Pangan yang Lestari. Artikel Pangan. Balai Besar Penelitian Tanaman Padi. Bogor: Vol. 19 No. 3: 233-243. http://www.jurnalpangan.com/index.php/pangan/article/download/150/136

Stewart J.I. 1991. Principles and Performance of Response Farming. In Climatic Risk in Crop Production. Models and Mangement for the Semi-Arid Tropics and Sub-Tropics. CAB Internasional Wallingford.

U. S. Geological Survey. 2019. Landsat 8 (L8) Data Users Handbook. Version 5.0. Department of the Interior U.S. Geological Survey. EROS. Sioux Falls. South Dakota. 114 hal.

Wahyunto. Widagdo dan Heryanto B. 2006. Pendugaan Produktivitas Tanaman Padi Sawah melalui Analisis Citra Satelit. Informatika Pertanian. Bogor: Balai Besar Penelitian dan Pengembangan Sumberdaya Lahan Pertanian. Vol. 15: 853-869. http://www.litbang.pertanian.go.id/warta-ip/pdf-file/2.wahyuntoipvol-15.pdf 